\title{
THE ROLE OF LYMPHOID TISSUE AND THE ADRENALS IN IMMUNITY
}

\author{
By Mary Barber and Albert Delaunay
}

'From the Pasteur Institute, Paris, and St. Thomas's Hospital Medical School, London

\section{INTRODUCTION}

\section{THE ROLE OF LYMPHOID TISSUE}

\section{r. Lymphocytes and the Production of Antibodies \\ 2. Plasma Cells and the Production of Antibodies} 3. Effect of Destruction of Lymphoid
Tissue on Antibody Formation

\section{INTRODUCTION}

According to the theory of Ehrlich (1898, see also Topley, 1933) all cells have 'side chains' or ' receptors' for the attachment of nutrient or other substances. In his view, antigens become attached to these receptors which, since the antigen is foreign to the cell, then lose their normal function. This stimulates the production of new receptors, which are shed and constitute specific antibodies. This theory would seem to imply that any cell is capable of producing antibodies if an antigen becomes attached to it. The majority of bacteriologists, however, have looked on antibody formation as the property of only certain types of cell and, until recently, the reticulo-endothelial system was regarded as the major site of antibody formation.

Following the work of McMaster and Huddack (1935), attention has been turned to the role of lymphocytes in the production of antibodies. Of these cells, described by Yoffey (1950) as the ' mystery cells of mammalian tissues,' we know neither the function nor the fate. In the last decade, however, a great deal of work has appeared on the pituitary-adrenal control of lymphoid tissue and the possible part played by the lymphocyte in bacterial infection and immunity.

Outstanding in this field has been the work of Dougherty, White and their colleagues. As the result of their investigations, these workers (Dougherty and White, 1947) have concluded that lymphocytes are a major source of antibodies and that both lymphocytes and antibody formation are under pituitary-adrenal control. Thus, in the opinion of these investigators, the injection of adreno-cortical hormones is followed by involution of lymphoid tissue, dissolution of lymphocytes and the release of normal or immune gamma globulin.

These far-reaching conclusions are by no means universally accepted: Many investigators approaching the problem from widely different angles, have entered the field. The literature on the subject has become vast and appears in diversity of journals. The present review is an attempt to bring together the experimental evidence and, where possible, assess its value.

\section{LYMPHOID TISSUE}

\section{r. Lymphocytes and the Production of Antibodies}

McMaster and Huddack (1935) published the first experimental evidence for the production of antibodies in lymph nodes. These workers found that when heat-killed suspensions of bacteria were - injected intradermally into the ears of mice, agglutinins appeared in the lymph nodes draining the corresponding ear about seven days later. At this time agglutinins had begun to make their appearance in the blood stream, but usually at a lower titre. No agglutinins were found in the lymph gland draining the opposite ear until about the twelfth day. Amputation of the injected ear two hours after injection did not affect the result. Two years later McMaster and Kidd (r937) showed a similar early production of antivaccinia virus principle in the lymph nodes draining the ear after injection of this antigen.

These observations have been greatly extended by the work of Ehrich and Harris, T. N., and their colleagues. In early studies Ehrich (Ehrich and Wohltrab, 1934, and Ehrich and Voigt, 1934) 
failed to find a correlation between reticuloendothelial proliferation and antibody titres following the injection of a staphylococcal vaccine, whereas the rise in antibody titre was found to parallel the activity of the Malphighian bodies of the spleen. Since the active cells in the latter were thought to be lymphoblasts, this led to a series of investigations into the production of antibodies by lymph glands. Ehrich and Harris, T. N. (1942), working with rabbits, injected typhoid vaccine into the left hind-foot-pad and sheep's red blood cells into the right. The subsequent appearance of agglutinins and haemolysins in the popliteal lymph node and afferent and efferent lymph was compared with histological changes in the lymph node and the output of lymphocytes. Antibody titres in the foot tissue and afferent popliteal lymph never reached significant levels. In the efferent lymph on the corresponding side antibodies began to appear in two to four days and reached their maximum level after six days. Their appearance was preceded by a sharp rise in the output of lymphocytes through the efferent lymph and.by lymphatic hyperplasia in the lymph gland. Harris, T. N., et al. (1945) gave rabbits similar injections and five, six or seven days later collected lymph from the efferent lymphatic of the popliteal nodes. The antibody content was estimated for whole lymph and for lymph plasma and cell extract separately. For the latter, the lymphocytes were separated by centrifuging, suspended in saline and extracted by freezing and thawing three times. In every case the cell extract gave higher antibody titres than the plasma, and the average difference was four-fold. When lymphocytes containing one type of antibody were suspended in plasma with the other type there was no uptake of antibodies by the lymphocytes but a release of antibodies from the cells into the suspension. The authors, therefore, concluded that the lymphocytes did not simply absorb antibodies but were concerned in their formation. Essentially similar results were obtained by Harris; S., and Harris, T. N. (1949), when influenza virus was used as the antigen. In contrast to the high antibody titres occurring in the efferent lymph of the lymph node draining the site of injection only insignificant titres were found in the tissue at site of injection, although this contained many macrophages (Ehrich et al., 1946).

It was assumed from the above experiments that the lymphocyte was concerned with the production of antibodies. Since, however, lymphocytes are not phagocytic cells, it occurred to Harris, T. N., and Ehrich (1946) that particulate antigens must be converted to a soluble form before they are available to the lymphocytes.
They thus investigated the production of antigen specific soluble material after the injection of sheep's red blood corpuscles or dysentery vaccine They identified such a substance in the tissue at site of injection, the draining lymph node and the efferent lymph. The quantity diminished slowly? in the infected tissue, but disappearea rapidly ing two to three days in lymph nodes and efferene lymph, its disappearance being succeeded by the appearance of antibodies.

In further experiments Harris, T. N., et. al (1948) studied the role of the thymus and spleen in antibody production. It was found tha? removal of the thymus did not affect the produc $\vec{\omega}$ tion of antibodies, and that when present the thymus only contained very low titres. The spleen also played little part in antibody formation. after subcutaneous injection of an antigen, but if the latter were injected intravenously, where thew spleen probably received the bulk of the antigero administered, comparatively high antibody titres్s were found in the spleen

Considerable evidence has appeared to confirm the work of Harris, T. N., and his colleagues $\overrightarrow{\dot{c}}$ Thus Kass (1945) has demonstrated the presence of gamma globulin in human lymphocytes obtained from the mesenteric lymph nodes. Roberts $e t$ of $l_{\mathrm{co}}$ (1948) studied the antibody titres of various tis minces taken from mice immunized against vân cines and sheep's red blood corpuscles and cubated in vitro for three hours in serum from non-immunized mice. They found that poolece lymphoid tissue from the thymus and mesenteric glands gave higher antibody titres than othe? tissues. Dougherty et al. (1944), working witl| mice, recorded the presence of immune globulin in the lymphocyte of lymph glands after immuniza tion with sheep erythrocytes and in 1945 recorded. the presence of antibodies to staphylococcal filo trates in normal and malignant (lympho-sarcomat. lymphocytes. Furthermore. a very large amoun of evidence on the lymphocyte in relation to immunity has accumulated from a study of the action of adreno-cortical hormones and will bछ discussed later.

Not all workers, howeyer, are in agreement wit the above observations. . Spear (1948) in a dis cussion of technique pointed out how easily results in such experiments could be distorted by quites small carry-overs of fluid containing antibodiesu Craddock et al. (1949) studied thoracic duct lymp fँ in cats immunized with typhoid vaccine. The failed to find any antibodies in. cell extracts: although supernatant lymph plasma and bloo $\$$ serum of all animals had demonstrable titres Habel et al. (1949), using a technique similar t ${ }_{0}$ that of Ehrich and Harris, T. N. (1942) and $\vec{\nabla}$ suspension of $S$. typhi-murium or Past. tularens 
as antigen, found slightly higher antibody titres in the popliteal gland on the inoculated side than that on the control side, but they did not regard the difference as significant. Harris, S., and Harris, T. N. (1950), in reply to Craddock et al., point out that the thoracic duct is likely to contain many lymphocytes from nodes having no access to the injected antigen and also that lymphocytes from antibody-forming nodes may have yielded their antibodies into the lymph plasma by the time they reach the thoracic duct. With regard to the work of Habel et al., Harris, S., and Harris, T. N. (1950) suggest that the dose of antigen of these workers was too large to get optimal differences. This paper (Harris, S., and Harris, T. N., 1950) also describes further experiments showing the importance of careful technique for accurate results.

\section{Plasma Cells and the Production of Antibodies}

Recently a number of papers have appeared, notably from Scandinavian workers, indicating that the plasma cell or its precursor, not the mature lymphocyte, is the main source of antibody production. The ball was set rolling by Bing and Plum, who in 1937 advanced the hypothesis that plasma cells were globulin producers. This was based on clinical observations of the correlation between hyperglobulinaemia and plasma cell proliferation in diseases, not including myelomatosis, such as various infections and some cases of leucopenia.

Bjorneboe and Gormsen (1943) injected rabbits intravenously with massive doses of polyvalent vaccines from mixed bacteria or a mixture of foreign proteins, every other day for up to two months. The animals were killed at various intervals for histological studies. From the $3^{\text {rd }}$ to the $5^{\text {th }}$ day of immunization, moderate plasma cell proliferation was seen in the spleen, lungs and liver. From the 6th day plasma cell proliferation was present in spleen, lungs, liver, kidneys, suprarenals, lymph glands and bone marrow. This proliferation increased until about the $13^{\text {th }}$ day, after which it remained constant until between the $3^{\text {Ist }}$ and 68th day. In the spleen the infiltration was massive, the pulp being dense with cells, almost all of which were plasma cells, interspersed with a few reticulum cells. There was no hyperplasia of follicles. Many 'plasmocellular reticulum' cells were seen, favouring the hypothesis that the plasma cells originated from reticulum cells. Massive plasma cell proliferation occurred, however, in the reticulum cell-free adipose tissue. The relation between titre of antibody formation and plasma cell proliferation was proportional. Thus there was an almost constant relation between antibody formation and splenic weight. In conclusion, the authors suggest that the failure of earlier workers to note plasma cell proliferation in immunity was because immunization was not sufficiently massive. In further similar experiments, Bjorneboe et al. (1947) showed that during immunization plasma cell proliferation occurred in almost all organs except the thymus, and that the latter showed only very small amounts of antibody. In a review of all the work of these Danish authors Gormsen (1950) concludes that the plasma cells are antibodyproducing functional stages of reticulo-endothelial cells.

More recently, Ringertz and Adamson (1950) and Marshall and White (1950) have shown a similar plasma cell proliferation of the organs of guinea-pigs and rabbits following the injections of a large variety of particulate and non-particulate antigens. Both these groups of workers also noted some hyperplasia of lymphoid tissue and the former suggest that, under the influence of an antigen, immature lymphocytes may be converted into antibody-producing plasma cells, instead of developing into mature lymphocytes.

The role of the plasma cell in immunity has been further amplified by the in vitro studies of Fagraeus (1947, 1948 and 1950). During the secondary response, elicited in rabbits by intravenous injections of living $S$. typhi, this investigator noted a great increase in plasma cells in the red pulp of the spleen simultaneously with the increase of circulating antibodies. The cells appeared to arise from reticulum cells, passing through a chain of development from transitional cell, to immature plasma cell to mature plasma cell. Fagraeus excised portions of spleen at various intervals and studied their capacity to form antibodies in vitro in tissue culture. She found that the red pulp, rich in plasma cells, produced far more antibodies than the lymph follicles, and that antibody production was maximum when transitional cells had been largely replaced ky immature plasma cells, which was the time at which antibody formation in vivo was rising or at its maximum, and receded when mature plasma cells predominated. She also noted that the thymus, which contained no plasma cells, was incapable of forming antibodies in vitro.

This work is confirmed by Keuning and Stikke (1950), who in similar studies conclude that the role of the immature plasma cell in antibody production is ' beyond doubt.' The latter workers, however, although they repudiate the idea that mature lymphocyte: produce antibodies, suggest that certain lymphoblastic cells of the Malpighian corpuscles may be involved in antibody production. These authors draw attention to the fact 
that Epstein in 1929, in a study of the histological picture of immunity, noted that phagocytic rietculo-endothelial cells give rise to aggregates of non-phagocytic round cells resembling plasma cells and other lymphoid elements.

Since the observations of the Scandinavian workers, Harris, T. N., and their colleagues have made a number of histochemical studies in rabbits of the lymph glands draining areas injected with various antigens (see Harris; T. N., and Harris, S., I948 and 1949; Ehrich et al., 1949; and Forman et al., 1949). Following the observation of Casperson (I94I) that cells actively forming new protein are characterized by large amounts of ribonucleic acid in their cytoplasm, these workers studied these lymph nodes stained with methylgreen and pyronine to demonstrate the presence of desoxyribonucleoprotein (stained green) and ribonucleoprotein (stained red).

Harris, T. N., and Harris, S. (1948 and 1949) found that in lymph nodes actively engaged in antibody formation, pyronine staining material (presumably ribonucleic acid) appeared first in cells resembling reticulum cells, then in young immature lymphocytes and then later in cells with progressively smaller and denser nuclei. No other cell types contained such material. When the concentration of ribonucleic acid was determined in aqueous extracts of the lymph nodes it was found that the peak concentration occurred just before the appearance of the maximum concentration of antibodies in the nodes. These workers thus adhere to their view that the lymphocyte is the primary source of antibodies. They point out that the cells containing ribonucleic acid appear to form a continuous series from transitional reticulum cells to mature lymphocytes and suggest that antigenic stimulation offers a means of studying lymphocytopoiesis.

Ehrich et al. (1949) and Forman et al. (1949) found that the cellular reaction of the lymph glands during the first six days after injection of an antigen consisted chiefly of plasma cells, first plasmoblasts and then mature plasma cells predominating. Most of the ribonucleoprotein as shown by pyronine staining was contained in these cells. Lymphocytes began to proliferate later, showing their greatest activity on the 9th day, when ribonucleoprotein and antibody formation had passed their peak. Thus these latter authors now agree with the Scandinavian workers that plasma cells and not lymphocytes are responsible for antibody formation.

\section{Effect of Destruction of Lymphoid Tissue on Antibody Formation}

In 1931, Dustin demonstrated that the chromosomes of certain cells of the animal body were peculiarly sensitive to a number of noxious agentso Among the most readily affected cells were cortica thymocytes, the lymphocytes occurring in ger 1 minal centres and the cells of the crypts of Liebere. kuhn in the small intestine. Destruction of thes cells or inhibition of mitosis was readily produce by such agents as colchicine, acridines or nitroge mustards, or by irradiation.

The effect of splenectomy on the action of these poisons was studied by Dustin and Zylberszae (193I), who found that such a procedure renderest the thymocytes resistant to the action of trypaflavine, whereas the lymphocytes and the cells of the small intestine remained equally sensitive t $\vec{\Theta}$ this compound after removal of the spleen. Thes: authors, therefore, regarded thymocytes ans lymphocytes as being different types of cell if. spite of their structural similarity. This is ano important point in view of the observations o\$ Harris, T. N., et al. (1945), Bjorneboe et al. (1947 and Fagraeus (1947) that the thymus does noor produce antibodies.

Miller (1950) showed that adrenalectomy in? creased the resistance of thymocytes and lympho cytes of rats to colchicine, podophyllotoxin anc nitrogen mustard, although the animals them $\Phi$ selves were more sensitive to these compounds after adrenalectomy. For a detailed study of the effect of nitrogen and sulphur mustards $\$$ lymphopoietic organs the reader is referred Kindred (1947).

Zylberszac (193I) drew attention to the fact that most of the chemotherapeutic agents then $\mathrm{i}$ 要 use (e.g. acridines, arsenicals, Bismuth and mer curial salts) as well as most bacterial toxins cause rapid destruction of thymocytes and lymphocytes and suggested that this action played a part if the overcoming of an infective agent. Favous (I947) studied the effect of bacterial products $\mathrm{OB}$. lymphocytes more carefully and showed that lymphocytes from tuberculous mice were speciz. cally lysed in vitro by tuberculin, whereas lymphos cytes from normal mice or mice infected with salmonellae were not. Similarly, lymphocytes from mice infected with salmonellae were specis fically lysed by a suspension of the same organisms? The work of later investigators, however, makes i clear that these cells can be destroyed in vivo b9 a wide variety of different factors and Selye (1937) regards a caryoclastic crisis of thymus and lymp@ glands as one of the numerous non-specific lesions produced by almost any noxious agent. In $194 \%$ Ickowicz demonstrated that such a crisis is af early and sensitive response of the animal to surgical injury.

The idea that leucotoxic agents might affec antibody response is not a new one. Thus Rus $\mathbb{B}$ (1915), Simmons and Jones (1915) and Hektoe 
(1916) all showed that intoxication with benzene led to leucopenia and a depression of circulating antibodies. In 1947 , Philips et al., in some careful studies on goats immunized against ricin, demonstrated that the anamnestic response of these animals to a further injection of ricin was always delayed and sometimes decreased by leucopenic doses of nitrogen mustards. Spurr (1947) found that similar treatment decreased the antibody response of rabbits to typhoid vaccine. Marshall and White (1950), however, failed to demonstrate any such effect on the response of rabbits to the injection of various vaccines and non-particulate antigens.. Approaching the problem from another angle, Karnoffsky et al. (1948) studied the growth of Strep. pyogenes in the serum of normal rabbits and rabbits who had previously been given intravenous injections of a nitrogen mustard. They found that the normal serum strongly inhibited the growth of these organisms, whereas serum taken six or nine hours after injection of the nitrogen mustard was much more favourable to their growth.

Many studies have also appeared on the effect of X-irradiation on antibody formation. Hektoen (1915) first demonstrated that total body exposure to ionizing irradiation suppressed the antibody response to antigens injected shortly before or shortly after irradiation. Jacobson (I949) subjected young adult rabbits to $800 \mathrm{r}$. total body X-radiation (a dose which destroys nearly all the lymphoid tissue of the body) and 24 hours later gave them an intravenous injection of sheep's red blood cells. Such animals produced either no haemolysins or very low titres. If the spleen or appendix were surgically mobilized and lead-protected prior to the irradiation, essentially normal haemolysinproduction occurred, even though lymphatic tissue in the unprotected areas of the body was largely destroyed.

Evans (1948) studied the response of humans with abnormal lymphocyte pictures to paratyphoid $B$ vaccine. A group of 30 patients with radiationinduced lymphopenia had lower antibody titres and produced them more slowly than normal people. Very poor antibody responses occurred in cases of lymphatic leukaemia, Hodgkin's disease, lymphosarcoma and lymphofollicular reticulosis. In myeloid leukaemia, however, a disease in which the lymph glands retain their morphological function to a greater extent, the antibody response was normal.

Recent work in connection with cortisone (see below) has suggested that not only is lymphoid tissue concerned with the production of antibodies but that the destruction of adult lymphocytes in immunized animals may lead to the liberation of antibodies into the circulation. As early as 1925
Murphy and Sturm found that if rabbits were exposed to dry heat before and after injection of an antigen, a marked lymphocytosis occurred, and was associated with a temporary increase in serum antibody titre. In 1945, Dougherty; Chase and White found that the administration of small doses of benzene increased the circulating antibodies in intact, but not in adrenalectomized, mice immunized against sheep's red blood corpuscles, and attributed this to destruction of lymphocytes and consequent liberation of antibodies from these cells.

III. THE FOLE OF THE ADRENAL GLANDS

r. Introduction

2. Pituitary-Adrenal Control of Lymphocytes

(a) Lymphoid Tissue

(b) Circulating Lymphocytes

(c) Bone Marrow

(d) Malignant Cells

(e) Mode of Action and in vitro studies

(f) Effect of other Endocrine glands

3. Pituitary-Adrenal Control of Antibody Formation

\section{CONCLUSION}

\section{THE ROLE OF THE ADRENALS}

\section{Introduction}

The idea that the adrenal glands are affected by bacterial diseases is no new one. Thus, Roux and Yersin (1889) and many others have drawn attention to the hyperaemia of the adrenals following administration of diphtheria toxin. Equally old is the notion that abnormalities of the adrenal gland have' an effect on lymphoid tissue. Thus Addison (1855) recorded lymphoid hyperplasia in a patient with suprarenal deficiency and Star (1895) observed that the thymus in a seventeenyear-old girl dying of Addison's disease was as large as that of a twelve-month-old child. The recent isolation of cortico-steroids with adrenocortical activity has led to a host of more detailed investigations of the effect of this gland on both lymphoid tissue and antibody response.

A relationship between the suprarenals, 'shock' and lymphoid tissue has now been established. Thus Selye (1937) and Selye and Foglia (1939) studied the non-specific response of the organism to injury, i.e. the so-called ' alarm reaction.' This they found was characterized by hypertrophy of the adrenal cortex, involution of the thymus and lymphoid tissue, degeneration and death of cells in various tissues and ulcer formation in the 
digestive tract, together with various biochemical changes in the blood and urine. Adrenalectomy prior to the injury prevented the involution of the lymphoid tissue characteristic of the alarm reaction, but apparently increased some other signs of this reaction.

\section{Pituitary-Adrenal Control of Lymphocytes} (a) Lymphoid Tissue

Reinhardt and Holmes (1940) showed that in adrenalectomized male rats maintained on sodium chloride for 45 days the thymus did not undergo the characteristic involution, and the spleen and glands were heavier than those of normal intact animals. Segal and Leblond (1938) found that if intact rats were subjected to $\mathrm{X}$-irradiation of the abdomen all the lymphatic tissue of the body underwent involution, but that if adrenalectomized rats were similarly irradiated, the thymus and lymph glands other than the abdominal were unaffected. Dougherty and White (1947) showed that adrenalectomy prevented the lymphoid tissue involution usually produced by fasting.

The injection of adreno-cortical extract (ACE) or glucocorticoids in large doses has been shown to cause involution of the spleen and thymus in rats (Moon, 1937 and 1940 ; Ingle, 1938 and 1940 ; and Aschkenasy et al., 1950), mice (Dougherty and White, I944; Molumut et al., 1950; and Antopol, 1950) and rabbits (Dougherty and White, 1944). Injections of pituitary adreno-trophic hormone (ACTH) in large doses have similarly been shown to cause involution of thymus 'and lymph nodes of normal intact rats but not adrenalectomized animals (Crede and Moon, 1940; Simpson et al., I943; and Dougherty and White, 1944). Dougherty and White (1945b and 1946b) made a careful study of the lymphoid tissue after a single large injection of ACE or ACTH in mice and rabbits and recorded early dissolution of medium and small lymphocytes in thymus, lymph nodes, spleen and Peyer's patches. This was associated with an increased development of immature plasma cells and, as well as this, many of the smaller lymphocytes developed increasedly basophilic cytoplasm. Aschkenasy et al. (1950) observed similar changes in the cells of the splenic follicles. All these authors appear to agree that the changes in lymphoid tissue are maximal one to six hours after injection and that within 24 hours the picture has usually returned to normal.

Yoffey and his colleagues (195I) examined the cervical lymph nodes and thymus in guinea-pigs six hours after the injection of ACTH or eschatin and found no evidence of marked degenerative changes, although in some instances the lymphoid masses were less densely packed than usual. Their findings, therefore, are in sharp contrast to the degenerative changes described by Dougherty and White (1945a, 1946b and 1947) in lymphor tissue of mice and rabbits. It must be borne mind, however, that guinea-pigs differ from rabbits and mice in vitamin $\mathbf{C}$ metabolism, which mig突 affect their reaction to adrenal hormones.

Most of the above workers were studying the effect of a single injection. Yoffey and Baxtef: (1946) found that repeated injections of large doses of ACE in rats lead to slight but definite hypertrophy of lymphoid tissue. Dougherty and White (1947), on the other hand, working wit mice, found that daily injections of adrenotrophif in such a large dose as I $\mathrm{mg}$. led to a significaripg and persistent decrease in the weight of lymphom tissue. It is, however, stated in this latter papes that a secondary stimulation of lymphoid tissye may follow the primary lymphocyte dissolution? thus under certain conditions leading to lymphos tissue hypertrophy.

Injections of adrenaline have also been foun to cause involution of lymphoid tissue in guinea pigs (Delaunay et al., I949), and conditions which cause a discharge of endogenous adrenaline suoh as haemorrhage, emotional excitement or insul l⿳⺈.⿲㇒丨丶 hypoglycaemia apparently have a similar effect in rats (Gellhorn and Frank, I948 and 1949; 8̂n Zwecker, 1948). Gellhorn and Frank conclede from their observations that adrenaline doesco act directly on lymphoid tissue, but stimule the secretion of adreno-cortical hormones. Tle lymphoid tissue involution regarded by Seliz (1937) and Selye and Foglia (1939) as characteristig of the ' alarm reaction' may result from a similar' mechanism.

Herland (1950) found that the influence of corticoids on the lymphoid tissue of adrenalect. tomized rats was conditioned by stress, being only very slight in the absence of the latte Dougherty and White (1947), however, found that the effect of ACE on normal and adrenalectomize mice was indistinguishable, whereas, of cours\&, ACTH was inactive in the absence of the adrenal glands.

\section{(b) Circulating Lymphocytes}

A circulating lymphocytosis following adrenale ${ }^{2}$ tomy has been shown to occur in rats (Dalton and Masson, 1940) and rabbits (Murphy and Sturr\$ 1947). Crafts (1941) failed to find such a change in rats and Thatcher et al. (1948), working wit cats, found that lymphocyte counts showed wide variations which had no relation to the presenge or absence of the adrenal gland. Edmadjian and his colleagues found that stress in mice was fop lowed by lymphopenia in intact but not adrenalectomized animals (Edmagdjian and Pineu令, 1945) and that glucose administration had a similår 
effect in rats (Edmadjian et al., 1946). In both cases activation of the adrenal gland was regarded as the mode of action.

Lymphopenia following the injection of ACE has been observed in rats (Dougherty and White, 1944; Yoffey et al., I946; and Netter and Mathe, 1949), rabbits (Dougherty and White, 1944) and hens (Shapiro, 1949). A similar change after ACTH has been reported in rats (Dougherty and White, 1944; and Reinhardt et al., 1944), dogs (Reinhardt et al., 1944), rabbits (Dougherty and White, 1944; and Fischel et al., 1949), hens (Shapiro, 1949) and humans (Hills et al., r948; Forsham et al., 1949; and Herbert and de Vries, 1949). All authors agree that the phenomenon is transitory and inconstant. Mason et al. (1948) treated a woman of thirty-two years with ACTH and observed no significant change in circulating lymphocytes until the 22nd day when there was a lymphopenia of three hours' duration.

In a general review and discussion of their results, Dougherty and White (1947) conclude that the lymphopenia following pituitary-adrenal hormones is a reflection of the lymphocyte dissolution in lymphoid tissue and results, therefore, from a failure of delivery. In their investigations, repeated injections of ACE did not necessarily cause a continued lymphopenia and sometimes even resulted in lymphocytosis. They suggest that a balance exists between lymphocyte dissolution, lymphocyte production and the removal of lymphocytes from the peripheral circulation and that dissolution might be a stimulus for increased synthesis.

Another possible cause of lymphocytosis after $\mathrm{ACE}$ is the effect of the latter on the spleen. Thus Hechter (1948) has shown that the addition of ACE to the spleen of rabbits in vitro leads to a discharge of lymphocytes. Furthermore, Stone and Hechter (1948) showed that the administration of ACE to adrenalectomized rats subjected to ' swim-stress' was followed by lymphocytosis, provided the spleen was in situ, but not in splenectomized animals.

The effect of ACTH or ACE on the lymphocytes of the thoracic duct is disputed. Thus Reinhardt and $\mathrm{Li}$ (1945) found that in rats injection of ACTH led to a rapid decrease in their number occurring within I 5 to 30 minutes and lasting for four to ten hours. They concluded that this resulted from a greatly reduced outpouring of these cells from the lymph glands, thus supporting the view of Dougherty and White that the lymphopenia caused by this hormone results from a failure of delivery. Yoffey, Reiss and Baxter (1946) report a drop in thoracic duct lymphocytes in cats after injection of ACTH. Valentine et al. (1948), on the other hand, found no change in lymphocyte counts of the thoracic duct lymph of cats after injection of $\mathrm{ACE}$.

\section{(c) Bone Marrow}

Yoffey et al. (195I) investigated the effect of adrenal hormones on the lymphocyte content of the bone marrow of the humerus of guinea-pigs. They record that six hours after the injection of ACTH or eschatin there was no demonstrable increase in damaged cells. Furthermore, they found a statistically significant increase in lymphocyte content after eschatin and an increase approaching a significant level after ACTH. In discussion they suggest that this rise results from an increased uptake of lymphocytes from the blood and might thus be an important factor in the development of lymphopenia following the injection of cortico-steroids.

\section{(d) Malignant Cells}

Murphy and Sturm (1944) recorded that rats could be partially protected against inoculations with lymphatic leukaemia cells by adrenal hormones. About 5 per cent. of untreated controls escaped leukaemia; treatment with DOCA or eschatin increased this to 20 to 30 per cent.; ACE in oil gave 40 to 60 per cent. protection and ACTH 40 to 75 per cent. Law and Spiers (1947) treated mice suffering from lymphatic leukaemix with ACE and record a rapid fall in circulating. lymphocytes together with involution of thymus and lymphoid tissue. Bass and Feigelson (1948) observed a similar regression of malignant lymphocytes in mice as a result of non-specific 'alarm' stimuli.

It would appear from the above results that malignant lymphocytes are as sensitive to adrenalcortical stimuli as normal lymphocytes. Green and Savigear (1948), however, from their studies of mitosis in epithelial cells conclude that the epidermis of mice can be rendered refractory to the antimitotic action of shock or cortisone by painting with a carcinogen.

\section{(e) Mode of Action and in vitro Studies}

It must be emphasized that the effect of a single injection of ACE or ACTH on the lymphoid tissue is agreed by all to be of very short duration, reversion to normal usually occurring within 24 hours. If, therefore, it results from widespread destruction of lymphocytes in the body it must be followed by an extremely rapid regeneration. The life of the normal lymphocyte is, however, extremely short (see Adams et al., 1945; Reinhardt and Holmes, 1946; and Drinker and Yoffey, 194I). A very rapid synthesis must therefore occur under normal conditions. Holman et al. (1947) record that an injection of ACE leads to an 
increase in serum peptidase in mice and suggest that this increase in enzyme activity reflects an acceleration of the 'turnover' of lymphoid tissue.

A number of experiments on the direct effect of $\mathrm{ACE}$ and cortico-steroids on lymphocytes in vitro have appeared and the results are somewhat conflicting. The lymphocyte is, of course, a difficult cell to work with in vitro since it is an end cell and does not multiply. In any sample of lymphocytes, therefore, many cells showing varying stages of degeneration will be present. Most of the investigators based their studies on the method of Schrek (1943), which consists essentially in making a suspension of lymphocytes by mincing thymus or lymph glands in normal, saline or some other physiological fluid and then taking samples at various intervals for unstained and eosin-stained counts. Schrek (r943) found that with certain toxins, for example Mocassin venom, almost 90 per cent. of lymphocytes were stained by eosin (thus indicating disintegration) within ten minutes and this was followed by lysis and disappearance of the cells.

Under similar conditions Schrek (1949) found that cortico-steroids only had a very slight effect on lymphocytes, and Robertson (1948) found that eucortone had no significant action. Feldman (I950) found that lipo-adrenal cortical extract had a dramatic toxic action on lymphocytes, compound $A$ a significant but less marked effect and compound $E$ no action. Hechter and Johnson (1949) found that $\mathrm{ACE}$ alone did not damage the lymphocytes, but with the addition of a lymphoid tissue extract or a brain homogenate caused lysis of lymphocytes. He found cortico-steroids, on the other hand, to be inactive even in the presence of lymphoid tissue extracts.

Delaunay et al. (I949) prepared similar suspensions of lymphocytes and studied their capacity to take up neutral red. This the authors regarded as a more sensitive method of detecting early degeneration than eosin staining, but even so, the addition of I I-dehydroxorticosterone caused no significant change. Finally Heilman (1945) studied lymphocytes in tissue culture and recorded that compound $E$ in concentrations of 1.25 to 50 $\mu \mathrm{g} . / \mathrm{ml}$. caused a moderate but significant decrease in migration of lymphocytes and an increased rate of degeneration of small and medium lymphocytes. The latter effect was also noted with compound $A$, but this did not inhibit migration.

\section{(f) Effect of other Endocrine Glands on Lymphoid Tissue}

Whilst the lymphocytes appear to be peculiarly susceptible to pituitary-adrenal stimuli, certain other endocrine glands are not without their effect on these cells. The thyroid gland seems to have an action which is the reverse of that of the adrenals. Thus Reinhardt and Wainman (19420才 found that thyroidectomy decreased and injection of thyroxin increased the weight of thymus, spleen and lymph glands in male rats. Marder (1940) showed a similar action of thyroxine on the lymphoid tissue of mice.

Chiodi (1940) found that male (testosteron and female (estrone or estradiolbenzoate) seg hormones caused atrophy of thymus in rats and Persike (1940) recorded that pregnancý in young mice led to thymus involution. Reinhardt an Wainman (1942), working with male rats, found that castration increased, whilst injections a testosterone decreased, the weight of thymus lymph nodes and spleen.

The spleen appears to play some part in thes lymphopenia induced by adrenal hormones. Thuiss Drury (1949) found that in rats adrenaline pros duced lymphopenia only if the adrenal gland and spleen were in situ. Ungar (1944 and 1945) has recorded that the 'alarm' reaction is in hibited by splenectomy. From his studies on the part played by various glands in response to shock he concluded that the pituitary responded to injury by secretion of ACTH, which led to th $\overrightarrow{5}$ release of an adrenal product which stimulated secretion of a splenic substance.

\section{Pituitary-Adrenal Control of Antibody Formation}

In 1944, Swingle and Rimington, in a review the role of the adrenal cortex in physiologica processes, drew attention to the fact that adrenales tomy lowers the resistance of animals to the injection of many antigenic substances. Thu adrenalectomized animals have been shown to bi highly susceptible to small amounts of diphtheria toxin (Belding and Wyman, 1926), typhoid vaccinie. (Take and Marine, I923), bacterial infection (Jaffę). H. L., and Marine, 1924; and Scott, 1927\$ foreign cells (Perla and Marmorston-Gotterma 1928 and 1929) and foreign serum (Flashmar, 1926). Perla and Marmorston-Gotterman (I928 and 1929) further showed that this lowered resis tance was associated with a reduced capacity $\overline{\overline{6}}$ form antibodies. Later workers recorded thâ resistance of adrenalectomized animals was ro stored to normal by injections of ACE (Hartmats and Scott, 1932; and Ettelson, 1941).

Fox and Whitehead (1936) studied the effect of injections of ACE on the production of haemoly tic antibodies to sheep's red blood cells in rats and rabbits. In both groups of animals prolonged administration of $\mathrm{ACE}$ at the time of the injection of erythrocytes led to an increase in the titre of haemolysins, especially in the early stages. The also drew attention to the fact that animals not 
treated with ACE showed a loss in weight during the early stages of immunization, whereas those receiving $\mathrm{ACE}$ did not lose weight at any stage of the experiment.

These observations have been amply extended by the investigations of Dougherty and White and their colleagues. White and Dougherty (1944 and 1945) reported an increase in serum proteins occurring at the time of maximum lymphoid tissue involution in mice and rabbits after injection of ACTH. In further studies (Dougherty, Chase and White, 1944) a group of 12 rabbits were given daily injections of sheep erythrocytes intravenously and four of the rabbits were also given daily injections of ACE. Between the sixth and tenth week all animals having ACE had higher titres of haemolysins than the controls, the average difference being about double. When nine rabbits with high titres were given a single injection of antigen alone or ACE alone, the former led to no increase in antibodies, whereas six hours after ACE a transitory rise (rather less than double) occurred. Dougherty, Chase and White (I945) also recorded an anamnestic response three to twenty-five hours after a single injection of ACE or ACTH to mice and rabbits previously immunized against sheep's red blood cells.

These authors conclude from their observations that three to six hours after an injection of $\mathrm{ACE}$ or ACTH there is involution of lymphoid tissue which leads to the release of serum proteins and antibodies into the circulation. Further experiments by these authors have confirmed their opinion. Thus electrophoretic studies on extracts of washed lymphocytes from the thymus and lymph glands of rabbits revealed the presence of a protein identical with the gamma globulin of rabbit serum (White and Dougherty, 1945). Total body X-radiation of mice previously immunized against sheep's red blood cells led to lymphocyte destruction and an increase in circulating gamma globulin and antibodies (Dougherty and White, 1946a). The rate of antibody production to sheep erythrocytes was increased in mice, rats and rabbits by the simultaneous administraction of ACE (Chase, White and Dougherty, 1946).

All authors, however, are not in agreement with these workers. One obvious objection to the wholesale application of their conclusions is that their studies have been based on a single antigen, sheep's red blood corpuscles, the antibodies of which do not lend themselves to precise quantitative measurement. Fischel et al. (1949) treated rabbits previously immunized against crystalline ovalbumin with ACTH or X-radiation. In both cases a fall in circulating lymphocytes occurred, but quantitative precipitin estimations revealed no anamnestic rise in antibodies. De Vries (1950), working with rabbits similarly immunized, failed to demonstrate an increase in antibody nitrogen after ACTH. Craddock et al. (1949), working with cats inoculated with typhoid vaccine, failed to demonstrate any change in the antibody content of thoracic duct lymph, following the injection of ACE.

Murphy and Sturm (1947) found that adrenalectomized rabbits with hypertrophied lymphoid tissue produced antibodies to horse serum far in excess of intact animals. Reduction of lymphoid hyperplasia by administration of ACE did not reduce antibody formation. This may have been due to a disruptive action of the hormone on lymphocytes leading to a more rapid release of immune globulin, but the authors concluded that it meant that antibody formation was not under the control of the adrenals.

Germuth and Ottinger (1950) studied the effect of compound $E$ and ACTH on the Arthus reaction and antibody formation to crystalline egg albumen in rabbits, and found that both substances inhibited sensitization and suppressed antibody formation.

A series of papers by Stoerk and his colleagues also attack the findings of Dougherty and White. The first investigation (Eisen et al., 1947) is concerned with the effect of adrenalectomy with or without injection of $\mathrm{ACE}$ on the production of antibodies by rats to a pneumococcal vaccine and sheep's red blood cells, both given to the same animal. They conclude from their observations that ACE may exert a transitory influence on the distribution of pre-existing antibodies, but that adrenal cortical activity has no prolonged effect on the production or release of antibodies and gamma globulin. A further paper (Stoerk et al., I947) records that the turnover of serum protein in the rat is unaffected by adrenalectomy or the administration of ACE. Finally, Stoerk and Solotorovsky (1950) found that the immune response of mice and rats including the anamnestic reaction was unimpaired by adrenalectomy, and that a single injection of cortisone in previously immunized rabbits was followed not by an anamnestic rise but by a drop in circulating antibodies.

Recently two troups of investigators have confirmed some of the findings of Dougherty and White. Thus Hammond and Noak (1950) were able to demonstrate an anamnestic response in rabbits immunized with sheep erythrocytes by the injection of ACTH. The rise in haemolysins was temporary, being maximum about nine hours after the injection of ACTH. Bussard et al. (1950) found that in rats highly immunized against both a salmonella vaccine and sheep's red cells an injection of ACE led to a temporary increase in 
circulating antibodies, which was maximum about eight hours after injection. Animals, however, immunized only against pneumococcal or salmonella vaccines did not show this rise in antibodies after ACE injection.

Roberts and White (1950) studied the production of antibodies in vitro by splenic tissue from rats which had had a single intravenous injection of sheep's red blood cells five days earlier. If the animals were normal the splenic tissue released large amounts of haemolysin; if animals had been adrenalectomized two to four days previously the release of antibodies was much smaller; if, on the other hand, the rats had been given an injection of ACE two to four days earlier, the splenic tissue produced an increased amount of antibodies in vitro. The authors considered that $\mathrm{ACE}$ both released antibodies from the spleen and increased the period of maximum antibody production.

In a more recent investigation (Roberts \& White, 195I) these authors have shown that the splenic production of antibodies in vitro may be significantly affected by adrenal cortical secretions without appreciably altering the level of circulating antibody. They suggest that one explanation for this discrepancy is that antibody removal from the blood by the tissues may also be dependent on adrenal secretion. Thus release and remova! of antibody may both be reduced in adrenalectumized and accelerated in hormone-treated animals. Such an explanation, if true, might also account for the divergent results obtained by different authors in in vivo experiments.

A few reports of the effect of ACTH and ACE on antibody response in humans have now appeared. Most of these are based on few experiments and it is, therefore, not surprising that the results are conflicting. Forsham et al. (1948) found that ACTH injections revealed no detectable increase in antibodies of two patients who had latent syphilis, one who had previously had T.A.B. vaccine and one who. had had mumps. One patient, however, who had previously been immunized with a pure pneumococcal type I polysaccharide showed a small rise in precipitin titre persisting for one week after starting ACTH administration. Mason et al. (1948) record no circulating gamma globulin in one patient on ACTH and Herbert and de Vries (1950) failed to demonstrate an increase in agglutinins in three patients previously vaccinated with T.A.B. who were given a single dose of ACTH, although all showed a temporary fall in circulating lymphocytes. Daughaday et al. (1948), on the other hand, gave a patient with a chromophobe adenoma of the pituitary three injections of a typhoid vaccine and then 40 cc. of ACE in two doses. This latter was followed in about six hours by a temporary fall in circulating lymphocytes plus a temporary rise in antityphoid agglutinins.

Mirick (195I) has recently made a more esten $\frac{3}{-0}$ sive study in human beings. He vaccinated $59^{\circ}$ patients with a mixture of pneumococcal polysaccharides and then 17 were treated with $\mathrm{ACTH}_{\vec{\rho}}$ and 12 with cortisone. Serum globulin, measured by zinc sulphate turbidity, was decreased in 1 zo of the 17 treated with ACTH and 6 of the 125 . treated with cortisone. Production of mouse $\Omega$ protecting antibodies was certainly not depressedy and seemed to be enhanced by treatment, but since the treated and untreated groups were not absolutely comparable as to age and diseases it is impossible to be certain that this was the effect of treatment. In I I treated cases the titre of iso: haemagglutinins was tested before and aften. treatment and in four instances there was a four-i fold increase. Of five patients with a titre of $I$ in 10 or more, of antityphoid $\mathrm{H}$ agglutinins two showed a four- to eight-fold drop. The authoriv suggests in discussion that in the presence of $\mathrm{a}^{\mathrm{T}}$ persisting antigenic stimulus such as that afforded by pneumococcal polysaccharide or the mechanism governing isohaemagglutinin production $=$ these drugs may cause enhanced antibody for mation, whereas when the stimulus is not per $\overrightarrow{0}$ sistent, as with previous exposure to typh क्षु bacilli, the result of treatment with ACTH cortisone may be a fall.

\section{CONCLUSION}

That lymphoid tissue, with the exception of the thymus, plays a considerable part in the production of antibodies seems beyond doubt $\overrightarrow{\overrightarrow{0}}$ The exact cell or cells concerned remains unproved, although a study of the available evidence suggests that immature cells resembling plasma. cells are the most active in this respect. It must? however, be emphasized that the cells of many. other tissues of the body are also capable of anti $\frac{3}{3}$ body formation and indeed recent work (Oakley 1950, 1951) tends to favour the view of Ehrliclo that under certain conditions any cell is capable of reacting to an antigen by the production of antibodies, although possibly not to the same extent as certain lymphoid cells.

It is clear that the lymphoid tissue of the bod is to some extent controlled by adrenal hormonestu That the injection of ACE or ACTH causes transitory circulating lymphopenia and decrease in weight of the lymphoid tissue of the body is certain. The underlying mechanism is less cleafo Thus Dougherty and White consider that ther is widespread lymphoid tissue degeneration and dissolution. Other workers, however, draw atten tion to the transitory nature of the phenomenom and suggest that a temporary failure of productio क्षि 
is more probable. In support of this is the fact that ACE has no dramatic effect on lymphocytes in vitro. The apparently increased number of degenerative pycnotic cells described by Dougherty and his colleagues in lymph nodes after injection of $\mathrm{ACE}$ or ACTH might be apparent rather than real resulting from a diminution in the number of healthy lymphocytes. In view of the rapidity with which the changes appear, however, some degree of lymphocytic dissolution seems probable. Excessive removal of lymphocytes from the blood, for example by the bone marrow as suggested by Yoffey et al. (I95I), may play a part. In this connection it is noteworthy that gluco-corticoids may in large doses inhibit the reproduction of many cells of the body, particularly fibroblasts (see Ragan et al., r949; Aterman, 1950; Coste, Basset and Delaunay, I95I; and Barber and Delaunay, 195I). Green and Ghadially (195I) suggest that cortisone has a general antimitotic action as a result of interference with carbohydrate utilization.

The role of the adrenals in the production of antibodies is much more debatable. Since it is almost certain that lymphoid tissue is both concerned with the production of antibodies and to some extent under pituitary-adrenal control, some connection between the adrenals and immunity might be expected. lt is, however, difficult to obtain unequivocal experimental proof of this. Theoretically, assuming that involution of lymphoid tissue follows the injection of $\mathrm{ACE}$ or ACTH, this might have one of two effects on the circulating antibody titre. Already formed antibodies might be released into the circulation, thus causing a rise in titre, or the production of further antibodies might be inhibited. If both mechanisms occurred at the same time, circulating antibodies might remain unchanged. The time of injection of the hormone in relation to immunity state is obviously all-important. In view of this, positive results are probably more important than negative ones. The results of Dougherty and White, therefore, must be given considerable weight. It is, however, unfortunate that they confined themselves to a study of haemolysin production and, as Fischel and his colleagues (r949) pointed out, it remains true that so far no one has demonstrated a significant alteration in antibody titre following injection of these hormones, with the use of an antigen such as crystalline ovalbumen, which gives rise to antibodies which lend themselves to accurate quantitative measurement. Finally, it must be borne in mind that in all the experiments referred to very large doses of hormone were used. It cannot, therefore, be assumedo that the results obtained are comparable to what occurs under normal physiological conditions.

\section{BIBLIOGRAPHY}

ADAMS, W. S., SAUNDERS, R. H., and LAWRENCE, J. S. (1945), Am. F. Phys., 144, 297.

ADDISON, T. (1855), 'On the Constitutional and Local Effects of Disease of the Suprarenal Capsules.' London, Samuel Highley.

ANTOPOL, W. (1950), Proc. Soc. exp. Biol., N.Y., 73, 262.

ASCHKENASY, A., BUSSARD, A., CORVAT.IER, P., and GRABAR, P. (1950), Rev. d'Hematologie, 5, 107.

ATERMAN, K. (1950), Lancet, ii, 517.

BARBER, M., and DELAUNAY, A. (195I), Ann. Inst. Pasteur. In the press.

BASS, A. D., and FEIGELSON, M. (1948), Proc. Soc. exp. Biol., N.Y., 69, 339 .

BELDING, D. L., and WYMAN, L. C. (1926), Am. F. Phys., 78, 50.

BING, J., and PLUM, P. (1937), Acta. Med. Scand., 103, 547.

BJORNEBOE, M., and GORMSEN, H. (1943), Acta. Path. and Micr. Scand., 20, 649.

BJORNEBOE, M., GORMSEN, H., and LUNDQUIST, F. (1947), F. Immunol., 55, 121 .

BUSSARD, A., CORVAZIER, P., GRABER, P., and ASCHKENASY, A. (1950), Rev. d'Hematologie, 5, 107.

CASPERSON, T. (1941), Naturissenschaften, 29, 33.

CHASE, J. H., WHITE, A., and DOUGHERTY, T. F. (1945), Endocrinol., 36, 16.

CHIODI, H. (1940), Ibid., 26, 107.

COSTE, H., BASSET, G., and DELAUNAY, A. (1951), C.R. Soc. Biol., 145, 39.

CRADDOCK, C. G., Jun., VALENTINE, .W. N., and LAWRENCE, J. S. (1949), Ұ.' Lab. Clin. Med., 34, 158.

CRAFTS, R. C. (1941), Endocrinol., 29, 596.

CREDE, R. H., and MOON, H. D. (1940), Proc. Soc. exp. Biol. N.Y., 43, 44.

DALTON, A. J., and MASSON, G. (1940), Ibid., 43, 370.

DAUGHADY, W. H., WILLIAMS, R. H., and DALAND, G. A. (1948), Blood, 3, 1342.
DELAUNAY A., DELAUNAY M., and LEBRUN, J. (1949), Ann. Inst. Past., 76, I.

DOUGHERTY, T. F., CHASE, J. H., and WHITE, A. (1944), Proc. Soc. exp. Biol., N.Y., 56, 78.

DOUGHERTY, T. F., CHASE, J. H , and WHITE, A. (1945), Ibid., 58, 135.

DOUGHERTY, T. F., and WHITE, A. (1944), Endocrinol., 35, 1 . DOUGHERTY, T. F., and WHITE, A. (1945a), Ibid., 36, 16.

DOUGHERTY, T. F., and WHITE, A. (1945b), Amer. F. Anat., 77, 8 r.

DOUGHERTY, T. F., and WHITE, A. (1946a), Endocrinol., 39, 370.

DOUGHERTY, T. F., and WHITE, A. (1946b), Anat. Rec. Suppl., 94, 13.

DOUGHERTY, T. F., and WHITE, A. (1947), F. Lab. Clin. Med., 32, 584 .

DOUGHERTY, T. F., WHITE, A., and CHASE, J. H. (1945), Proc. Soc. exp. Biol., 59, 172.

DRINKER, C. K., and YOFFEY, J. M. (194I), 'Lymphocytes, Lymph and Lymphoid Tissue.' Harvard Univ. Press.

DRURY, A. (1949), Fed. Proc., 8, 37.

DUSTIN, A. P. (1931), C.R. Soc. Biol., 108, 1155.

DUSTIN, A. P., and ZYLBERSZAC, S. (193I), Ibid., 108, 1162.

EDMADJIAN, F., and PINEUS, G. (1945), Ibid., 37, 47.

EDMADJIAN, F., FREEMAN, H., and PINEUS, G. (1946), Ibid., 39, 293.

EHRICH, W. E., DRABKIN, D. L., and FORMAN, C. (1949). F. exp. Med., 90, 157.

EHRICH, W. E., and HARRIS, T. N. (1942), Ibid., 76, 335 .

EHRICH, W. E., HARRIS, T. N., and MERLENS, E. (1946), Ibid., 83, 373.

EHRICH, W. E., and VOIGT, W. (1934), Beit. path. Anat. u. alls. Path., 93, 321.

EHRICH, W. E., and WOHLTRAB, R. (1934), Ibid., 93, 348.

EHRLICH, P. (1898), Deuts. med. Wschr., 24, 597. 
EISEN, H. N., MAYER, M. M., MOORE, D. H., TARR, R. R., and STOERK, H. C. (1947), Proc. Soc. exp. Biol., N.Y., 65, उ०r.

EPSTEIN, E. (1929), Virchows. Arch.f. path. Anat., 273, 89.

ETTELSON, L. N. (1941), Endocrinol., 27, 340.

EVANS, R. W. (1948), F. Path. Bact., 60, 123.

FAGRAEUS, A. K. (1947), Nature, 159, 499.

FAGRAEUS, A. K. (1948), $\mathcal{F}$. Immunol., 58, I.

FAGRAEUS, A. K. (1950), Le Sang, 21, 480.

FAVOUR, C. B. (1947), Proc. Soc. exp. Biol., N.Y., 65, 269.

FELDMAN, J. D. (1950), Endocrinol., 46, 552.

FISCHEL, E. C., LE MAY, M., and KABAT, E. A. (1949), $\mathcal{f}$. Immunol., 6r, 89.

FLASHMAN, D. H. J. (1926), 7. Inf. Dis., 38, 46r.

FORMAN, C., EHRICH, W. E., and DRABKIN, D. L. (1949), Fed. Proc., 8, 355.

FORSHAM, P. H., THORN, G. W., PRUNTY, F. T. G., and HILLS, A. G.'(1948), Ұ. clin. Endocrinol., 8, I5.

FOX, C. A., and WHITEHEAD, R. W. (1936), $f$. Immunol., 30, 5 I.

GELLHORN, E., and FRANKS, S. (1948), Proc. Soc. exp. Biol., N.Y., 73, 399.

GELLHORN, E., and FRANKS, S. (1949), Ibid., 71, 112.

GERMUTH, F. G., Jun., and OTTINGER, B. (1950), Ibid., 74, 815 .

GORMSEN, H. (1950), Le Sang., 21, 483.

GREEN, H., and GHADIALLY, F. N. (195I), Brit. med. f., i, 496 .

GREEN, H., and SAVIGEAR, M. (I95 I), Ibid., i, 498.

HABEL, K., ENDICOTT, K. M., BELL, J. F., and SPEAR, F. (1949), $\}$. Immunol., 6r, 131 .

HAMMOND, C. W., and NOAK, M. (1950), Proc. Soc. exp. Biol., $N . Y ., 74,155$.

HARRIS, S., and HARRIS, T. N. (1949), F. Immunol., 61, 193.

HARRIS, S., and HARRIS, T. N. (1950), Ibid., 64, 45 .

HARRIS, T. N., and EHRICH, W. E. (1946), ₹. exp. Med., 84, 157.

HARRIS, T. N., GRIMM, E., MERLENS, E., and EHRICH W. E. (1945), Ibid., 81, 73.

HARRIS, T. N., and HARRIS, S. (1948), Proc. Soc. exp. Biol., N.Y., 69, 18.

HARRIS, T. N., and HARRIS, S. (1949), f. exp. Med., 90, 169.

HARRIS, T. N., RHOADS, J., and STOKES, J. (1948), $\mathcal{f}$. Immunol., 58, 27.

HARTMAN, F. A., and SCOTT, W. J. M. (r932), f. exp. Med., 55,63 .

HECHTER, O. (1948), Endocrinol., 42, 285.

HECHTER, O., and JOHNSON,'S. (1949), Ibid., 45, $35 \mathrm{I}$.

HEKTOEN, L. (1916), ₹. Inf. Dis., r9, 69.

HEILMAN, D. (1945), Proc. Staff Meetings Mayo Clin., 20, 311.

HERBERT, P. H., and DE VRIES, J. A. (1949), Endocrinol., 44, 259.

HERLANT, M. (1950), Proc. Soc. exp. Biol., N.Y., 73, 399.

HILLS, A. G., FORSHAM, P. H., and FINCH, C. A. (1948), Blood, 3, 755.

HOLMAN, H. R., WHITE, A., and FRUTON, J. S. (1947), Proc. Soc. exp. Biol., 65, 196.

ICKOWICZ, M. (1947), Radiologica Clinica, 16, 231.

INGLE, D. J. (1938), Proc. Soc. exp. Biol., N.Y., 38, 443.

INGLE, D. J. (1940), Ibid., 44, 174.

JACOBSON, L. D., ROBSON, M. E., MARKS, E. K., and GOLDMAN, B.' S. (1949), $尹$. Lab. clin. Med., 34, 16 2.

JAFFE, H. L., and MARINE, D. (1924), $\mathcal{F}$. inf. Dis., 35, 334.

KARNOFFSKY, D. A., GRAEFF, I., and SMITH, H. W. (1948), Am. F. Path., 24, 275.

KASS, E. H. (1945), Science, ror, 337.

KEUNING, F. J., and SLIKKE, L. B. VANDER (1950), f. Lab. clin Med., 36, 167.

KINDRED, J. E. (1947), Arch. Path., 43, 253.

LAW, L. W., and SPIERS, R. (1947), Proc. Soc. exp. Biol., N.Y., $66,226$.

MCMASTER, P. D., and HUDDACK, S. S. (1935), Ұ. exp. Med., $6 \mathrm{I}, 783$.

MCMASTER, P. D., and KIDD, J. C. (1937), Ibid., 66, 73.

MARDER, S. N. (1949), Proc. Soc. exp. Biol., N.Y., 72, 42.

MARSHALL, A. H. E., and WHITE, R. G. (1950), Brit. F. exp. Path., 31, 157.

MASON, H. L., POWER, M. H., RYNEARSON, E. H. CIARAMELLi,I, L, C., LI, C., and EVANS, H. M. (1948),
Э. clin. Endocrinol., 8, I.

MILIER, Z, B. (1950), ₹. exp. Med,, 92 , 113.

MIRICK, G S. (1951), Bull. Э. Hopkins Hosp., 88, 332.

MOLOMUT, N., SPAIN, D. M., and HABER, A. (1950), Proc. Soc. exp. Biol., N.Y., .73, 416 .
MOON, H. D. (1937) Ibid., 37, 34 .

MOON, H. D. (1940), Ibid., 43, 42.

MURPHY, J. B., and STURM, E. (1925), f. exp. Med., 41, 245.

MURPHY, J. B., and STURM, E. (r944), Science, 99, 303.

MURPHY, J. B., and STURM, E. (1947), Proc. Soc. exp. Biol.; N.Y., 66, 303.

NETTER, A. and MATHE, G. (1949), Le Sang., 20, 442.

OAKLEY, C. L., WARRACK, G. H., and BATTY, I. (1949)7. Path. Bact., 6r, 179.

OAKLEY, C. L., BATTY, I., and WARRACK, G. H. (1951)을

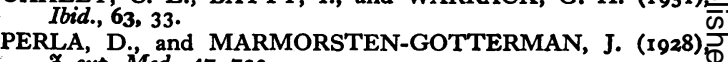
F. exp. Med., 47, 723 .

PERLA, D., and MARMORSTEN-GOTTERMAN, J. (1929) RSICKE, E. C., Jun. (1940), Proc. Soc. exp. Biol.. N.Y., 45, 315PHILLIPS, F. S., HOPKINS, F. H., and FREEMAN, M. L. H. (1947), F. Immunol., 55, 289.

RAGAN, C., CROKOEST, A. W., and BOOTS, R. H. (1949) $\vec{\omega}$ Amer. $\mathscr{F}$. Med., I00, 74r.

RAGAN, C., HOWES, E. L., PLOTZ, C. M., MEYER, K., and BLÚNT, J. W. (1949), Proc. Soc. exp. Biol., N.Y., 72, 7180

REINHARDT, W. O., ARON, H., and LI, C. (I944), Ibid., 57, 289 .

REINHARDT, W. O., and HOLMES, R. O. (1940), Ibid., 45, 267 N

REINHARDT, W. O., and HOLMES, R. O. (1946), Anat. Rec. $\bigodot$ 94, 197.

REINHARDT, W. O., and LI, C. (1945), Science, ror, 360.

REINHARDT, W. O., and WAINMAN, P. (1942), Proc. Soc exp. Biol., N.Y., 49, 257.

RINGERTZ, N., and ADAMSON, C. A. (1950), Acta. Path. et Mia. Scand. Suppl., 86.

ROBERTS, S., ADAMS, E., and WHITE, A. (1948), f. Biol? Chem., 174, 379.

ROBERTS, S., and WHITE, A. (1950), Fod. Proc., 9, 220.

ROBERTS, S., and WHITE,"A. (1951), Endocrinol, 48, 74 I.

ROBERTSON, J. S. (1948), Nature, 161, 814.

ROUX, E., and YERSIN, A. (1889), Ann. Inst. Pasteur, 3, 273. $\overrightarrow{0}$

RUSK, G. Y. (1915), Univ. California Publ. Path., 2, 139.

SCHREK, R. (1943), Arch. Path., 35, 857.

SCHREK, R. (1949).

SCOTT, W. J M. (1927), f. exp. Med., 47, 185

SEGAL, G., and LEBLOND, C. P. (1938), C.R. Soc. Biol., 279 .

SELYE, H. (1937), Endocrinol., 21, 160.

SELYE, H., and FOGLIA, V. G. (1939), Amer. F. Anat., 64, 1330

SHAPIRO, 1. B. (1949), Proc. Soc. exp. Biol., N.Y., 70, 440.

SIMMONS, J. P., and JONES, H. M. (1915), F. med. Res., 28. 197

SIMPSON, M. E., LI, C., REINHARDT, W. O., and EVANS $\overline{\bar{O}}$ H. M. (1943), Proc. Soc. exp. Biol., N.Y.,, 54, I35.

SPEAR, F. (1948), F. Lab. clin. Med., 33, 1563.

SPURR, C. L. (1947), Proc. Soc. exp. Biol., N.Y., 64, 259.

STAR; P. (1895), Lancet, i, 284.

STOERK, H. C., JOHN, H. M., and EISEN, H. N. (1947), Proco Soc. exp. Biol., N.Y., 66, 25. STOERK, H. C., and SOLOTOROVSKY, M. (1950), Am. F

STONE, D., and HECHTER, O. (1948), Endocrinol., 42, 307.

SWINGLE, W. M., and RIMINGTON, J. W. (1944), Phys. Rev. 24, 89 .

TAKE, M. N., and MARINE, D.'(1923), Y. inf. Dis., 33, 217.

THATCHER, J. S., HOUGHTON, B. C., and ZIEGLER, C. H $\Phi$ (1948), Endocrinol., 43, 440.

TOPLEY, W. W. C. (1933), 'An Outline of Immunity.'

UNGAR, G. (1944), Nature; $154,736$.

UNGAR, G. (1945), Endocrinol., 37, 329.

VALENTINE, W. N., CRADDOCK, C. G., and LAWRENCEO J. S. (1948), Blood, 3; 729 .

DE VRIES, J. A. H. (1950), F. Immunol., 65, I.

WHITE, A., and DOUGHERTY, T. F. (1944), Proc. Soc. expev Biol., N.Y., 56, 26.

WHITE, A., and DOUGHERTY, T. F. (1945), Endocrinol., 36, 2075 WHITE, A., and DOUGHERTY, T. F. (1947), Ibid., 4I, 230. YOFFEY, J. M. (1950), Biol. Rev., 25, 314.

YOFFEY, J. M., and BAXTER, J. S. (1946), Ұ. Anat., 80, x32. YOFFEY, J. M., METCALFE, W. K., HERDAN, G., and NAVIN, V. (195I), Brit. med.' y., i, 660.

YOFFEY, J. M., REISS, M., and BAXTER, J. S. (1946), Nature r54, 368 .

ZWECKER, I. T. (1948), Am. Y. Phys., 152, 267.

ŻYLBERSZAC, S. (193i), C.R. Soc. Biol., 108, 1156. 